\title{
Developing English language competence for specialists in rocket and space composite structures
}

\author{
Inna Shafikova ${ }^{1, *}$, Galina Gurova ${ }^{1}$, and Andrey Novikov ${ }^{1}$ \\ ${ }^{1}$ Bauman Moscow State Technical University, 105005 Moscow, Russia
}

\begin{abstract}
Composite materials is a rapidly developing field of science and technology. Training specialists in composite materials requires special approach with regard to their English language competence. The paper looks at the proposed English language course for Rocket and space structures. The course in question must comply with the requirements of the Bologna process, curriculum and education standards and at the same time meet the learners' needs in terms of their professional competence. A multi-level system is proposed that includes academics apart from undergraduate and postgraduate students.
\end{abstract}

Composite materials continue to find new applications in rocket and space engineering. Valuable combination of properties make composites a material of choice when it comes to demanding applications in extreme conditions. Innovative, energy-efficient manufacturing technologies make composites an economically feasible solution. Current education trends in Russia and abroad manifest increased interest in training specialists to work in the fields of composite materials design, manufacture and testing.

Existing teaching methods and courses must be reevaluated within regard to the contemporary requirements. The most important factor is that since 2003, after signing the convention on the mutual recognition of diplomas and certificates, Russia is in the process of integration into the global education system, the so-called Bologna process. The Bologna doctrine prescribes system of credit units for the learning outcomes assessment, adequate accreditation procedures, two-tier architecture of academic degrees, transparency of information flows for all education modules, and introduction of the new diploma supplements. All of the above must lead to academic mobility, as well as compatibility and comparability of diplomas and qualifications, and, ultimately, through integration, increase competitiveness of the European higher education system. The aim of this initiative is to unify the European education system as a response to globalization, to ensure its quality and uniformity worldwide.

In spite of the numerous organizational challenges associated with the transitional period, Russia can expect significant benefits for its education system, once the Bologna doctrine is fully implemented. For one, Russian universities will be a part of the international education market. Additionally, recognition of Russian academic degrees globally will stimulate

* Corresponding author: shafikova_inna@mail.ru 
academic exchange, thus fostering scientific progress. However, the achievements of the past must be preserved, while the Russian academic standards are brought in line with the European requirements [1].

The English language teaching is one of the spheres most seriously affected by the Bologna process. It is evident that higher proficiency in one or several European languages is a prerequisite to academic mobility. Consequently, the approach to the English language teaching courses needs to be modified. The main trends are:

- courses in English for Specific Purposes (ESP) tailored for the specific professional activity;

- life-long learning, i.e. designing a range of courses to enable continuous improvement of the professional communicative competence;

- diversification of the second language learning system, so that the needs of students with different aims and different abilities are provided for;

- equal access to the foreign language learning for the students from various backgrounds;

- global unification of the second language learning and increased academic mobility;

- information technology skills enabling autonomous learning;

- learner-centered approach; i.e. accounting for the learners' various needs and planning the course accordingly [2-4].

Another important factor is the insufficient English-language competence of the university academics. Some sources suggest that this aspect is hindering the internalization of the Russian higher education into the global education market $[5,6]$.

New generation of the educational standards and curricula for the Bachelor's and Master's degree programs in rocket complexes and space studies (24.03.01; 24.04.01 majors) contains requirements with regard to the English (or another second) language competence. The graduates are expected to be capable of conducting literature research, preparing reports and presentations for scientific conferences and communicating in the target language in the academic and professional contexts.

All of the above considerations were taken into account when designing an English language curriculum for the students and teachers of Rocket and Space composite structures department at Bauman MSTU (Fig. 1). The choice of the course content is governed by the demands of the industry specified in the professional standards and by the learners' needs, which are diagnosed via needs analysis.

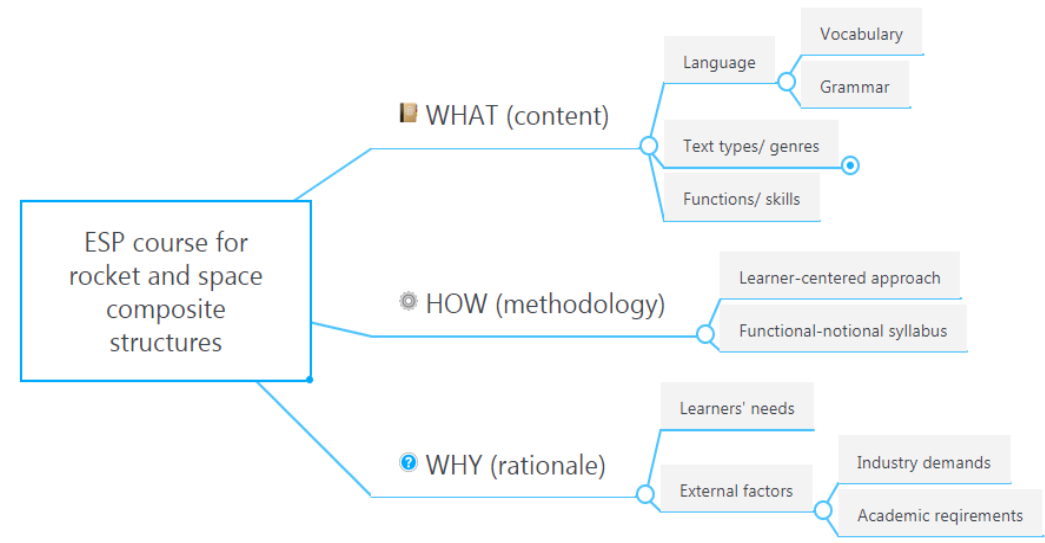

Fig. 1. ESP course for rocket and space composite structures' content, methodology and rationale.

The syllabus of an ESP course must be consistent with the specialized courses taught at the department under consideration. This principle ensures that the students are aware of the 
importance of the English language for their future profession. It also helps to supplement and support the specialized content. Below (Table 1) is a proposed syllabus of English for rocket and space composite structure course. It takes into account the content of the specialized courses taught to the undergraduate students [7]. The same principle should equally be applied to a Master's degree course, since some Master's degree students hold a Bachelor's degree in a different field of engineering and thus would especially benefit from an ESP course tailored for the department curriculum.

Table 1. Proposed syllabus for English for rocket and space composite structure course.

\begin{tabular}{|c|c|c|c|}
\hline $\begin{array}{r}\text { Course } \\
\end{array}$ & Function & Vocabulary & Grammar \\
\hline $\begin{array}{l}\text { Technology of processing and } \\
\text { modifying new materials }\end{array}$ & $\begin{array}{lr}\text { Explaining } & \text { needs, } \\
\text { problems } & \text { and } \\
\text { solutions; } & \\
\text { stating objectives; }\end{array}$ & $\begin{array}{l}\text { Composites } \\
\text { manufacturing } \\
\text { processes verbs }\end{array}$ & $\begin{array}{l}\text { Modals, } \\
\text { Infinitives } \\
\text { of purposes }\end{array}$ \\
\hline $\begin{array}{l}\text { Fundamentals of physics, } \\
\text { chemistry, and fabrication of } \\
\text { composites }\end{array}$ & Describing a process & $\begin{array}{l}\text { Physics, chemistry } \\
\text { terms }\end{array}$ & Conditionals \\
\hline CAD basics & $\begin{array}{l}\text { Explaining } \\
\text { dimensions; } \\
\text { working } \quad \text { with } \\
\text { drawings }\end{array}$ & $\begin{array}{l}\text { Specifications } \\
\text { dimensions }\end{array}$ & \\
\hline $\begin{array}{l}\text { History of research in } \\
\text { composites }\end{array}$ & Sequence of events & & Past tenses \\
\hline $\begin{array}{ll}\text { Composite } & \text { structures } \\
\text { mechanics } & \end{array}$ & Explaining forces & Physical forces & \\
\hline Principles of scientific research & $\begin{array}{l}\text { Describing methods, } \\
\text { giving definitions }\end{array}$ & & $\begin{array}{l}\text { Relative } \\
\text { clauses }\end{array}$ \\
\hline $\begin{array}{l}\text { Polymer composite structures } \\
\text { development }\end{array}$ & $\begin{array}{l}\text { Describing use or } \\
\text { function; } \\
\text { describing shape } \\
\text { and appearance }\end{array}$ & $\begin{array}{l}\text { Composite materials, } \\
\text { properties. } \\
\text { Shapes of composite } \\
\text { parts }\end{array}$ & $\begin{array}{l}\text { Noun } \\
\text { attributes }\end{array}$ \\
\hline $\begin{array}{l}\text { Technology of reusable space } \\
\text { vehicles }\end{array}$ & $\begin{array}{l}\text { Describing parallel } \\
\text { processes }\end{array}$ & $\begin{array}{l}\text { Stages in a composites } \\
\text { fabrication process }\end{array}$ & $\begin{array}{l}\text { Passive } \\
\text { voice }\end{array}$ \\
\hline Composite media mechanics & $\begin{array}{l}\text { Describing motion, } \\
\text { forces }\end{array}$ & $\begin{array}{l}\text { Verbs to denote } \\
\text { movement }\end{array}$ & \\
\hline $\begin{array}{l}\text { Optimization of composite } \\
\text { structures and procedures }\end{array}$ & $\begin{array}{l}\text { Expressing purpose; } \\
\text { expressing } \\
\text { strengths/ } \\
\text { weaknesses }\end{array}$ & $\begin{array}{l}\text { Processes sequence/ } \\
\text { simultaneity; } \\
\text { Types of composites } \\
\text { fabrication equipment }\end{array}$ & $\begin{array}{l}\text { Purpose } \\
\text { clause }\end{array}$ \\
\hline
\end{tabular}

A multi-level system was proposed for the Rocket and space composite structures department at Bauman MSTU. The novelty of such system is that apart from undergraduate and postgraduate students it also includes academics. The assumption was that the academics will need to increase their proficiency in English for their own purposes, such as dealing with international information sources, participating in international conferences, conducting business and academic correspondence, and interacting with students from abroad [8,9]. At the same time, academics who are proficient in English will stimulate their students' English language-related activity. Another stimulating factor was the participation of teachers and postgraduate students in scientific conferences in the UK, organized jointly by the Bauman MSTU and the University of Glyndwr in North Wales. As a result, the publication activity increased noticeably. The number of foreign students is constantly growing at the department, with academic communication conducted not only in Russian, but also in English. All this testifies to the effectiveness of the developed methods. 


\section{References}

1. N.Yu. Pimenova, Universitetskoye upravleniye: praktika i analiz 1, 15 (2006)

2. T.D. Margaryan, I.H..Margaryan, Eur. Social. Sc. J. 3, 256 (2017)

3. N.N. Nikolaeva, Humanities Bulletin of BMSTU 7 (2017)

4. T.Y. Polyakova, Vestnik Moscow State Ling. Univ. 12 (618), 9 (2011) [in Russian]

5. E. Frumina, R. West, Internationalisation of Russian Higher Education: The English Language Dimension (British Council, Moscow, 2012)

6. K.M. Inozemtseva, Higher ed. Russia, 5, 145 (2014)

7. I. R. Shafikova Advanced Composite Materials and Technologies for Aerospace Applications, 83 (2013)

8. M.V. Zosimov, V.A. Moiseyev, I.R. Shafikova, S.A. Shorokhov, Vestnik Kostromskogo gos. univ. 23 (3), 127 (2017)

9. I. R. Shafikova, Vestnik Tomsk. gos. ped. univ. 10, 160 (2017) 